\title{
Administration of GnRH on the day of fixed-time artificial insemination (FTAI) and melengestrol acetate (MGA) administration after ftai in non-suckling nelore cattle
}

\section{Aplicação de GnRH no dia da inseminação artificial em tempo fixo (IATF) e administração de acetato de melengestrol (MGA) após iatf em vacas nelore solteiras}

\author{
Rossane Pereira da Silva ${ }^{1 *}$; Karen Martins Leão ${ }^{2}$; \\ Moraima Castro Rodrigues ${ }^{1}$; Thaisa Campos Marques ${ }^{3}$; \\ Natalia do Carmo Silva; ${ }^{3}$ Marco Antônio de Oliveira Viu ${ }^{4}$
}

\begin{abstract}
The present study evaluated the effect of administering buserelin acetate $(\mathrm{GnRH})$ at the time of fixedtime artificial insemination (FTAI), along with the effect of oral administration of melengestrol acetate (MGA) after FTAI on conception rates in non-suckling Nelore cattle. In Experiment I, the effect of GnRH application at the time of FTAI was evaluated, as was administration of MGA from the $13^{\text {th }}$ through the $18^{\text {th }}$ day following FTAI (D24 to D29 after the initiation of the FTAI protocol). Experiment I was performed in 215 non-suckling cattle of the Nelore breed, divided into four experimental groups: Control group: 56 cows subjected to FTAI without GnRH injection; GnRH group: 51 cows subjected to GnRH at the time of FTAI; MGA Group: 57 cows subjected to FTAI without the application of GnRH with mineral supplementation and the addition of $2.28 \mathrm{~g}$ of $\mathrm{MGA}^{\circledR}$ Premix per cow per day from D24 to D29 after the initiation of the FTAI protocol; MGA and GnRH group: 51 cows subjected to GnRH injection at the time of FTAI, with mineral supplementation and the addition of $2.28 \mathrm{~g}$ of $\mathrm{MGA}^{\circledR}$ Premix per cow per day from D24 to D29 after the initiation of the FTAI protocol. In Experiment II, the effect of providing MGA five to ten days after FTAI was evaluated in 196 non-suckling pluriparous Nelore cows, divided into two groups: Control group: 104 cows subjected to FTAI, not supplemented with MGA; treated group: 92 cows supplemented with the addition of $2.28 \mathrm{~g}$ of $\mathrm{MGA}^{\circledR}$ Premix per cow per day from D15 to D20 after the initiation of the FTAI protocol. Diagnosis of gestation was carried out 45 days after FTAI. Both experiments were conducted using a completely randomised design and analysed via the SAS MIXED procedure. In Experiment I, the control group displayed a lower conception rate (32.1\%) compared with the groups administered GnRH, MGA, and both MGA and GnRH, which were respectively provided with MGA after FTAI (45.6\%), GnRH at the time of FTAI (50.9\%), and the combination of the two treatments $(50.9 \%)(\mathrm{P}<0.05)$. In Experiment II, the control group displayed a higher conception rate $(40.38 \%)$ compared with the group receiving MGA post-FTAI $(18.48 \%)$ $(\mathrm{P}<0.05)$. It was concluded that the injection of buserelin acetate $(\mathrm{GnRH})$ at the time of FTAI and the oral administration of $\mathrm{MGA}^{\circledR}$ Premix from the $13^{\text {th }}$ to the $18^{\text {th }}$ day after FTAI increased the conception rates in non-suckling Nelore cattle. However, when $\mathrm{MGA}^{\circledR}$ Premix was administered orally from the fifth to tenth day post-FTAI, conception rates in non-suckling Nelore cattle were reduced.

Key words: Uterine environment, progestogens, maternal recognition, ovulation synchronisation, conception rate
\end{abstract}

\footnotetext{
Mestres em Zootecnia, Instituto Federal Goiano, IF GOIANO, Rio Verde, GO, Brasil. E-mail: rossane_rv@hotmail.com; moraima_rv@hotmail.com

2 Prof $^{\mathrm{a}} \mathrm{Dr}^{\mathrm{a}}$, Instituto Federal Goiano, IF GOIANO, Rio Verde, GO. Brasil. E-mail: karenleao2@yahoo.com.br

3 Discentes do Curso de Doutorado em Zootecnia, Universidade Federal de Goiás, UFG, Goiânia, GO, Brasil. E-mail: thaisacm@ hotmail.com; nataliazootec@hotmail.com

4 Prof. Dr., Universidade Federal de Goiás, UFG, Jataí, GO, Brasil. E-mail: marcoviu@yahoo.com.br

* Author for correspondence
} 


\section{Resumo}

Avaliou-se o efeito da aplicação de Acetato de Buserelina (GnRH) no momento da IATF e o efeito do fornecimento, via oral, de Acetato de Melengestrol (MGA) após IATF, sobre a taxa de concepção em vacas solteiras da raça Nelore. No Experimento I, avaliou-se o efeito da aplicação de GnRH no momento da IATF e do fornecimento de MGA do décimo terceiro ao décimo oitavo dia após a IATF (D24 ao D29 após o início do protocolo de IATF), em 215 vacas solteiras da raça Nelore divididas em quatro grupos experimentais; grupo Controle: 56 vacas submetidas à IATF sem aplicação de GnRH; Grupo GnRH: 51 vacas submetidas à aplicação de GnRH no ato da IATF; Grupo MGA: 57 vacas submetidas à IATF sem aplicação de GnRH e suplementação mineral, com adição de 2,28g de $\mathrm{MGA}^{\circledR}$ Premix/vaca/dia do D24 ao D29 após o início do protocolo de IATF; Grupo MGA e GnRH: 51 vacas submetidas à aplicação de GnRH no momento da IATF e suplementação mineral com adição de 2,28g MGA ${ }^{\circledR}$ Premix/vaca/dia do D24 ao D29 após o início do protocolo de IATF. No Experimento II, avaliou-se o efeito do fornecimento de MGA cinco a dez dias após a IATF em 196 vacas pluríparas solteiras da raça Nelore, divididas em dois grupos experimentais; grupo Controle: 104 vacas submetidas à IATF sem fornecimento de MGA, e grupo Tratado: 92 vacas suplementadas, com adição de 2,28g de $\mathrm{MGA}^{\circledR}$ Premix/vaca/dia do D15 ao D20 após o início do protocolo de IATF. Realizou-se diagnóstico de gestação 45 dias após a IATF. Ambos os Experimentos foram conduzidos em delineamento inteiramente casualizado, analisados através do procedimento MIXED do SAS. No Experimento I, o grupo controle obteve menor taxa de concepção $(32,1 \%)$ comparado com os demais grupos avaliados quando fornecido MGA após a IATF $(45,6 \%)$, GnRH no momento da IATF (50,9\%), bem como a associação dos dois tratamentos $(50,9 \%)(\mathrm{P}<0,05)$. No experimento II, o grupo controle obteve maior taxa de concepção (40,38\%) quando comparado com o grupo que recebeu MGA pós-IATF $(18,48 \%)(\mathrm{P}<0,05)$. Conclui-se que a aplicação de Acetato de Buserelina $(\mathrm{GnRH})$ no momento da IATF e o fornecimento, via oral, de $\mathrm{MGA}^{\circledR}$ Premix, administrado do décimo terceiro ao décimo oitavo dia após a IATF elevou a taxa de concepção em vacas Nelore solteiras. Entretanto, quando administrado do quinto ao décimo dia pós-IATF, o fornecimento, via oral, de $\mathrm{MGA}^{\circledR}$ Premix reduziu a taxa de concepção em vacas Nelore Solteiras.

Palavras-chave: Ambiente uterino, progestágenos, reconhecimento materno, sincronização de ovulação, taxa de concepção

\section{Introduction}

The oestrous cycle of cows is controlled by complex neuroendocrine interactions coordinated by the hypothalamic pituitary gonadal axis and by an intra-ovarian mechanism that establishes follicular dynamics, allowing the development of a mature follicle with the capacity to undergo ovulation at the opportune time, thus producing a cell capable of being fertilised (CALLEJAS, 2001).

In beef cattle, just as important as the pregnancy is the distribution of pregnancies during the breeding season. Oestrus synchronisation is a technique that helps to optimise the use of time, manpower and financial resources by shortening the calving period and producing an increased weight and uniformity of the products (DAHLEN et al., 2003).

Fixed-time artificial insemination (FTAI) protocols can induce synchronisation of oestrus, and particularly ovulation, in cyclic females, in addition to reducing postpartum anoestrus and treating ovarian cysts. Therefore, controlled hormone therapy, when properly applied in herds, may contribute to an increased reproductive efficiency, ensuring that the cost/benefit ratio is favourable to producers (MURTA et al., 2001).

Cattle exhibit high fertilisation rates (AHMAD et al., 1995; CERRI et al., 2009); however, one of the main factors involved in the loss of a pregnancy is uterine deficiency in foetal nutrition and pregnancy maintenance, which causes embryonic death (SARTORI, 2004). In contrast to what occurs in primates and mice, in cattle, embryo implantation and placentation do not take place immediately after fertilisation; instead, the conceptus spends an extended period of time in the uterine lumen before fixing itself to the endometrium (BAZER et al., 2009). 
Low conception rates can be caused by several factors, but the most common cause is embryonic loss during the initial stages of pregnancy. However, two main factors influence embryonic loss: the quality of the ovulated oocyte and uterine support of embryonic development (KRUSE et al., 2013). The quality of the oocyte can be regulated by the circulating levels of progesterone $\left(\mathrm{P}_{4}\right)$ before ovulation (PFEIFER et al., 2009), while uterine function can be regulated by the circulating levels of progesterone after ovulation (BARUSELLI et al., 2004).

Supplementation with progesterone increases the embryonic growth rate as well as the embryo's ability to produce interferon-tau (IFN- $\tau$ ), a molecule that signals the embryo's presence in the uterus (SATTERFIELD et al., 2006). Beltman et al. (2009) reported that higher circulating concentrations of progesterone after conception induce increased pregnancy rates.

According to Ayad et al. (2007), higher concentrations of $\mathrm{P}_{4}$ may promote a more suitable uterine environment for embryonic development, resulting in a larger conceptus and greater production of trophoblast proteins such as IFN- $\tau$ and pregnancy-associated glycoproteins, which, unlike IFN- $\tau$, reach the maternal blood circulation and are used for pregnancy diagnosis.

Melengestrol acetate $\left(\mathrm{MGA}^{\circledR}\right.$ Premix) is an orally administered progestin that is recommended for improving embryo implantation and increasing conception rates in cows in postpartum anoestrus by assisting in synchronisation of oestrus and inducing ovulation (WOOD-FOLLIS et al., 2004).

The administration of synthetic buserelin acetate $(\mathrm{GnRH})$ analogues exerts physiological effects in females, inducing the pre-ovulatory peak of luteinising hormone (LH) and, consequently, ovulation and/or follicle luteinisation, causing a new wave of follicular growth (GOTTSCHALL et al., 2008).

Given the above, the present study aimed to evaluate the effect of administering $\mathrm{GnRH}$ at the time of FTAI and the effect of orally administering MGA (MGA ${ }^{\circledR}$ Premix, Pfizer, Huvepharma Inc., St. Louis, Missouri, USA) after FTAI, either from the $13^{\text {th }}$ day (D24) to the $18^{\text {th }}$ day (D29), or from the fifth day (D15) to the tenth day (D20) after FTAI, on the conception rates of non-suckling Nelore cattle.

\section{Materials and Methods}

To evaluate the effect of administering GnRH at the time of FTAI and the effect of providing MGA from day 24 (D24) to day 29 (D29) after the initiation of the FTAI protocol, Experiment I was developed, which was conducted at a property located in the city of Rio Verde, state of Goiás (GO), Brazil. The experimental animals were kept in paddocks with Tanzania grass (Panicum maximum Jacq. cv. Tanzania) and provided with water troughs for $a d$ libitum consumption of water and with covered troughs containing CRIA 91 - F.1 mineral salt $\left(\mathrm{COMIGO}^{\circledR}\right.$, Rio Verde, Goiás - Brazil) provided ad libitum for all animals.

\section{Evaluation and preparation of animals for} Experiment I

For this experiment, 215 non-suckling pluriparous Nelore cows were selected, showing body condition scores between 3.0 and 3.5 (on a scale of 1 to 5 , with 1 being very thin and 5 being very fat, according to FERGUSON et al., 1994).

For the synchronisation of ovulation, each cow received a first use intravaginal progesterone device on day zero (D0) containing 1.9 grams of progesterone $\left(\mathrm{CIDR}^{\circledR}\right.$, Pfizer, São Paulo, Brazil) and $2.0 \mathrm{mg}$ of oestradiol benzoate (EB, Gonadiol ${ }^{\circledR}$, Coopers, Luis Guillón, Buenos Aires). After seven days (D7), $0.15 \mathrm{mg}$ of D-cloprostenol (PGF, Croniben $^{\circledR}$, Biogenesis Bago, Mercês, Curitiba, Brazil) was administered. On the ninth day (D9), the $\mathrm{P}_{4}$ device was removed, and $0.6 \mathrm{mg}$ of oestradiol cypionate $\left(\mathrm{CE}, \mathrm{ECP}^{\circledR}\right.$, Pfizer, São Paulo, Brazil) 
was administered. On day 11 (D11), FTAI was performed, and the females treated with GnRH at the time of FTAI were subjected to the administration of $0.004 \mathrm{mg}$ of GnRH (SincroForte ${ }^{\circledR}$, Ourofino, Cravinhos, Brazil). Inseminations were performed with semen from an Aberdeen Angus bull from the same batch by four trained inseminators, with each inseminator performing the technique on the same number of animals per group (Figure 1).

Figure 1. Fixed-time artificial insemination protocol (Experiment I).

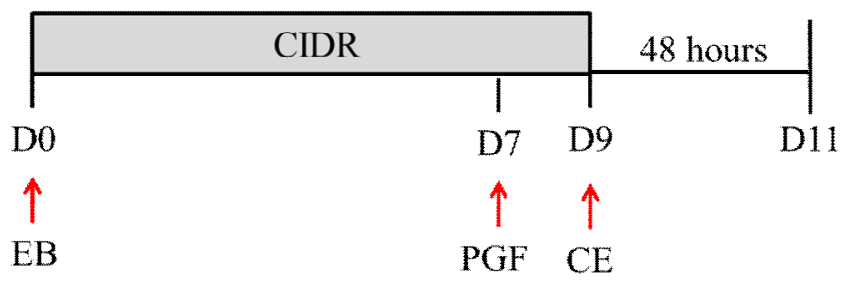

\section{Experiment I groups}

The animals were divided into four groups. In group I (Control), 56 animals received mineral supplementation according to their requirements, without the addition of melengestrol acetate, and were subjected to FTAI without the injection of GnRH. In group II (GnRH), 51 animals received mineral supplementation according to their requirements, without the addition of MGA, and were given an injection of GnRH at the time of FTAI. In group III (MGA), 57 animals were subjected to FTAI without the injection of GnRH and received mineral supplementation with the addition of $2.28 \mathrm{~g}$ of MGA (MGA ${ }^{\circledR}$ Premix, Pfizer, Huvepharma Inc., St. Louis, Missouri, USA) per cow per day from the $24^{\text {th }}$ day (D24) after the initiation of the FTAI protocol, continuing to the $29^{\text {th }}$ day (D29). In group IV (GnRH and MGA), 51 animals were given an injection of GnRH at the time of FTAI and received mineral supplementation with the addition of $2.28 \mathrm{~g}$ of MGA (MGA ${ }^{\circledR}$ Premix, Pfizer, Huvepharma Inc., St. Louis, Missouri, USA) per cow per day from D24 to D29 after the initiation of the FTAI protocol, as shown in Figure 2.

To control the consumption of the $\mathrm{MGA}^{\circledR}$ Premix, at 8:00 am on D24, $2.28 \mathrm{~g}$ of $\mathrm{MGA}^{\circledR}$ Premix was mixed with four $\mathrm{kg}$ of mineral salt per animal, as suggested by the manufacturer. This mixture was supplied in a collective covered trough due to the impossibility of managing the provision of the supplement in individual troughs. At noon, the trough was observed; if there was no supplement remaining, then more was provided without $\mathrm{MGA}^{\circledR}$ Premix to ensure that the animals did not lack the mineral supplement. If there was remaining salt mixed with the $\mathrm{MGA}^{\circledR}$ Premix in the trough, it was left to be completely consumed before additional mineral salt, without $\mathrm{MGA}^{\circledR}$ Premix, was supplied. On the next day at 8:00 am, any remnants of the pure mineral supplement were removed from the trough before additional mineral supplement, with $\mathrm{MGA}^{\circledR}$ Premix, was supplied. This procedure continued until D29.

To evaluate the effect of providing MGA $\left(\mathrm{MGA}^{\circledR}\right.$ Premix, Pfizer, Huvepharma Inc., St. Louis, Missouri, USA) between the fifth and tenth days post-FTAI (D15 to D20), Experiment II was developed and conducted at a property located in the municipality of Itarumã, GO, Brazil. The experimental animals were kept in paddocks with Brachiaria brizantha cv Marandu grass and provided with drinking troughs for water and covered troughs to supply mineral salts ad libitum. 
Figure 2. Description of Experiment I groups.
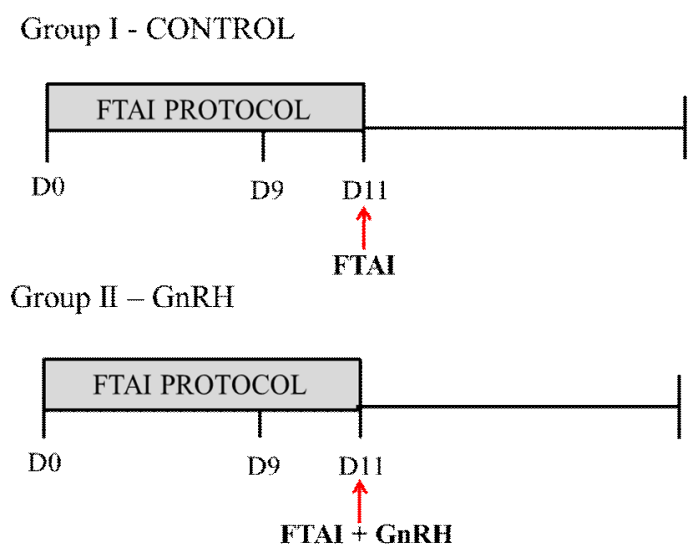

Group III - MGA

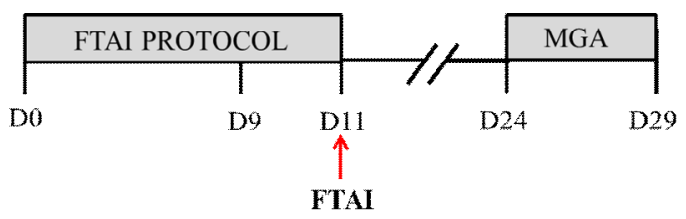

Group IV - GnRH and MGA

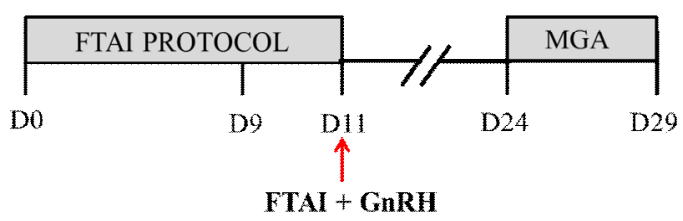

Evaluation and preparation of animals for Experiment II

For this experiment, 196 non-suckling pluriparous Nelore cows were selected, showing body condition scores between 3.0 and 3.5 (on a scale of 1 to 5 , with 1 being very thin and 5 being very fat, according to FERGUSON et al., 1994).

For the synchronisation of ovulation, each cow received a bovine intravaginal device containing $1.0 \mathrm{~g}$ of progesterone (DIB ${ }^{\circledR}$, MSD animal health, Cotia - SP) and $2.0 \mathrm{mg}$ of EB (Gonadiol ${ }^{\circledR}$, Coopers, Luis Guillón, Buenos Aires) on day zero (D0). After seven days (D7), $0.265 \mathrm{mg}$ of PGF (Ciosin ${ }^{\circledR}$, Coopers, Brasil) was administered to the cows. On day eight (D8), the $\mathrm{P}_{4}$ devices were removed, and $300 \mathrm{IU}$ of equine chorionic gonadotropin
(eCG, Novormon ${ }^{\circledR}$, Syntex S.A. - Argentina) and $1 \mathrm{mg}$ of EC (Cypionate $\mathrm{HC}^{\circledR}$, Hertape Calier, MG) were administered. On day 10 (D10), FTAI was performed. The inseminations were performed with semen from a Nelore bull from the same batch by a trained inseminator (Figure 3).

\section{Experimental groups of Experiment II}

The animals were divided into two experimental groups: in group I (Control), 104 animals received mineral supplementation according to their requirements without the addition of MGA; in group II (Treated), 92 animals received mineral supplementation with the addition of $2.28 \mathrm{~g}$ of MGA per cow per day from D15 to D20 after the initiation of the FTAI protocol, as shown in Figure 4. 
Figure 3. Fixed-time artificial insemination protocol (Experiment II).

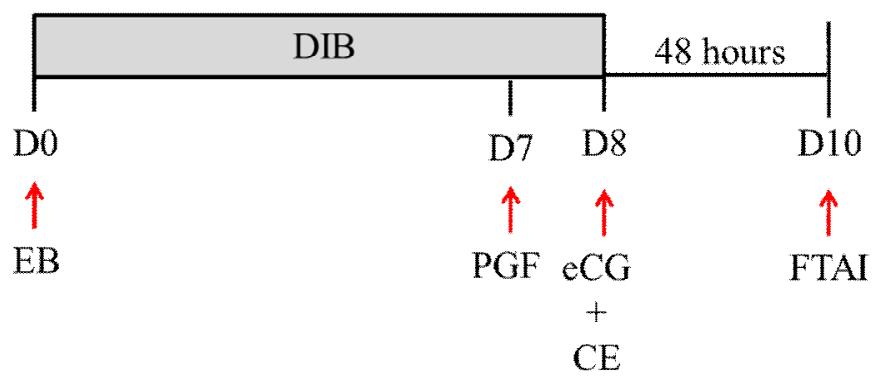

Figure 4. Description of Experiment II groups.

Group I - CONTROL

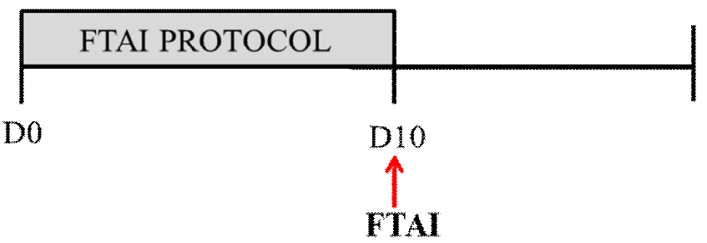

Group II - TREATED

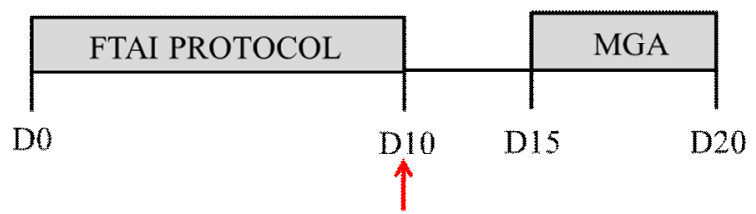

FTAI

A control consisting of $\mathrm{MGA}^{\circledR}$ Premix consumption, supplied from D15 to D20, was carried out as described in Experiment I.

\section{Pregnancy diagnosis}

Prior to initiating the experimental protocols, during the selection of cows for use in both experiments, ultrasound examination was performed on each cow to exclude pregnant cows from the study.

Pregnancy diagnosis for both experiments was carried out through ultrasound examinations performed 45 days after FTAI (Chison 600VET, linear transducer $5 \mathrm{MHz}$, China). Clean-up bulls were not used.

\section{Statistical design}

Both experiments were conducted using a completely random design. The conception rates recorded during the experiments were analysed using the SAS MIXED procedure (SAS, 2000).

\section{Results and Discussion}

When the effects of GnRH administered at the time of AI and MGA administered from the $24^{\text {th }}$ to the $29^{\text {th }}$ day after the initiation of the FTAI protocol in non-suckling Nelore cows were evaluated, it was found that when cows were only subjected to FTAI, with no additional treatment, conception rates were low (32.1\%) compared with the other groups evaluated, which were provided with MGA after 
FTAI (45.6\%), GnRH at the time of FTAI (50.9\%), and the combination of the two treatments $(50.9 \%)$, as shown in Table $1(\mathrm{P}<0.05)$. In Experiment II, the control group displayed a higher conception rate $(40.38 \%)$ compared with the group receiving MGA post-FTAI $(18.48 \%)(\mathrm{P}<0.05)$. However, there was no difference between the groups treated with GnRH (50.9\%), MGA (45.6\%) and MGA and GnRH (50.9\%), (Table 1, P>0.05).

Table 1. Conception rates of non-suckling Nelore cows subjected to FTAI without progesterone supplementation (Control); to GnRH injection at the time of FTAI (GnRH); to supplementation with MGA from the $24^{\text {th }}$ to $29^{\text {th }}$ day after the initiation of the FTAI protocol (MGA); or to GnRH injection at the time of FTAI and supplemented with MGA from the $24^{\text {th }}$ to $29^{\text {th }}$ day after the initiation of the FTAI protocol (MGA and GnRH).

\begin{tabular}{lcc}
\hline \multicolumn{1}{c}{ Groups } & N & $\begin{array}{c}\text { Conception Rate } \\
\text { (Pregnant/Inseminated) }\end{array}$ \\
\hline Control & 56 & $32.1 \%(18 / 56) \mathrm{b}$ \\
GnRH & 51 & $50.9 \%(26 / 51) \mathrm{a}$ \\
MGA & 57 & $45.6 \%(26 / 57) \mathrm{a}$ \\
MGA and GnRH & 51 & $50.9 \%(26 / 51) \mathrm{a}$ \\
\hline
\end{tabular}

*Different letters in the column indicate differences at a $5 \%$ probability level $(\mathrm{P}<0.05)$.

With the administration of GnRH at the time of FTAI, there was an increase in the conception rate from $32.1 \%$ (FTAI) to $50.9 \%(\mathrm{GnRH})$, a result similar to that found by Lopez-Gatius et al. (2006), who worked with dairy cows and observed that the animals that did not receive GnRH exhibited a conception rate of $20.6 \%$, while animals that did receive GnRH at the time of FTAI displayed a conception rate of $30.8 \%$. The results obtained by Moura (2008) demonstrated that the animals that received no GnRH at the time of FTAI showed a $57.14 \%$ conception rate, while cows treated with GnRH at the time of FTAI presented a conception rate of $62.96 \%$.

Gottschall et al. (2012) evaluated the effects of the use of an ovulation synchronisation protocol, involving the administration of GnRH in conjunction with FTAI as an inducer of ovulation and weaning, on the conception rates of lactating beef cows and did not observe significant differences in conception rates for the animals receiving $\mathrm{GnRH}$ (53.8\%) compared with those that did not receive GnRH $(53.2 \%)$ at the time of FTAI. These results differ from those obtained in the present study, in which positive effects on the conception rates of non-suckling Nelore cows were observed when they were subjected to GnRH injection at the time of FTAI.

Perry and Perry (2009) evaluated the effects of $\mathrm{GnRH}$ application in conjunction with $\mathrm{AI}$ on the conception rates in beef cattle that came into oestrus after an oestrus synchronisation protocol $(\mathrm{GnRH}$, $\mathrm{CIDR}^{\circledR}$ and PGF2 $\alpha$ ) and did not observe differences in conception rates between the evaluated groups. The authors reported a $68 \%$ conception rate in the group treated with $\mathrm{GnRH}$ in conjunction with $\mathrm{AI}$ and a $66 \%$ conception rate in the control group. These authors also reported that the application of $\mathrm{GnRH}$ at the end of oestrus in conjunction with insemination promotes a decrease in the concentration of $\mathrm{LH}$, which causes a reduction of the serum concentrations of progesterone and $\mathrm{LH}$ receptors in luteal cells, decreasing the maternal recognition capacity and embryo maintenance.

Siqueira et al. (2008) evaluated FTAI protocols using $\mathrm{EB}$ as the ovulation inducer and observed conception rates similar to those associated with conventional AI techniques and FTAI with GnRH. In postpartum beef cows, these authors observed 
oestrus for two days after implant removal and PGF2 $\alpha$ administration associated with FTAI using $\mathrm{GnRH}$ to induce ovulation in cows that did not exhibit oestrus and found that superior conception rates $(54.7 \%)$ occurred compared with the exclusive use of FTAI with oestradiol benzoate (33.3\%). According to Sartori et al. (2001), the asynchrony of follicular growth and the size of dominant follicles at the time of the LH peak are factors that determine the variation in reproductive responses to different protocols, similar to the results obtained in the present study.

Colazo et al. (2008) conducted a study designed to evaluate the response to $\mathrm{GnRH}$ in the induction of LH release under high levels of $\mathrm{P}_{4}$ in both heifers and cows and observed that elevated levels of plasma $\mathrm{P}_{4}$ reduced the release of LH by the pituitary gland after $\mathrm{GnRH}$ administration in both heifers and cows, in a linear fashion. The effects of $\mathrm{GnRH}$ administration at the time of insemination are connected to the uniform induction of a pre-ovulatory surge of $\mathrm{LH}$ and the anticipation of ovulation in cows with delayed ovulation (SÁ FILHO et al., 2011).

Corrêa et al. (2009) demonstrated that GnRH optimises the process of luteinisation and increases the concentration of circulating $\mathrm{P}_{4}$, favouring the maintenance of the embryo. The conception rates observed in the GnRH and the GnRH plus MGA groups were similar, differing only from the control group when employing FTAI. The use of GnRH in association with MGA does not appear to be economically feasible for increasing the rate of conception in non-suckling Nelore cows.

The present study shows that supplementation with progesterone from the $13^{\text {th }}$ to the $18^{\text {th }}$ day after FTAI increases the conception rate in nonsuckling Nelore cows, as shown in Table 1, with the MGA group presenting a higher conception rate (45.6\%) than the control group (32.1\%) without $\mathrm{P}_{4}$ supplementation following FTAI. According to Ayad et al. (2007), higher concentrations of $\mathrm{P}_{4}$ could promote a more suitable uterine environment for embryo development, resulting in a larger conceptus and greater production of trophoblastic proteins such as INF- $\tau$ and glycoproteins associated with conception, which unlike INF- $\tau$, reach the maternal blood circulation and are used to diagnose pregnancy.

The increase in conception rates observed in the treated groups in Experiment I can be explained by the findings of Stronge et al. (2005), who reported that high circulating concentrations of $\mathrm{P}_{4}$ following conception are associated with conceptus elongation as well as an increase in the production of IFN- $\tau$ and, consequently, higher conception rates in cows.

When the effect of providing MGA from D15 to D20 after the initiation of the FTAI protocol in non-suckling Nelore cows was evaluated, it was observed that when cows were subjected only to FTAI without additional treatment, they achieved a higher conception rate $(40.38 \%)$ compared with the group that was provided with MGA after FTAI $(18.48 \%)(\mathrm{P}<0.05)$, as shown in Table 2.

Table 2. Conception rates of non-suckling Nelore cows subjected to FTAI without progesterone supplementation (Control) or supplemented with melengestrol acetate (MGA) from the $15^{\text {th }}$ to the 20 th day after the initiation of the FTAI protocol (Treated).

\begin{tabular}{lcc}
\hline Groups & N & $\begin{array}{c}\text { Conception Rate } \\
\text { (Pregnant/Inseminated) }\end{array}$ \\
\hline Control & 104 & $40.38 \%(41 / 104) \mathrm{a}$ \\
Treated & 92 & $18.48 \%(17 / 92) \mathrm{b}$ \\
\hline
\end{tabular}

*Different letters in the column indicate differences at a $5 \%$ probability $(\mathrm{P}<0.05)$. 
It was noted in the present study that supplying MGA from the $24^{\text {th }}$ to the $29^{\text {th }}$ day after the initiation of the FTAI protocol increased the conception rate $(45.6 \%)$ compared with the FTAI group in Experiment I (32.1\%). However, in Experiment II, the control group showed a higher conception rate (40.38\%) compared with the group treated with MGA from D15 to D20 after the initiation of the FTAI protocol (18.48\%).

Mann et al. (2006) reported that supplementation with $\mathrm{P}_{4}$ from day five (D5) to day nine (D9) after conception quadruples the length of the trophoblast and increases the uterine concentration of IFN- $\tau$ by six-fold in non-lactating Holstein cows compared with supplementation of $\mathrm{P}_{4}$ between days 12 and 16. However, this correlation is not observed in non-suckling Nelore cows, as the present study demonstrated improved conception rates compared with the control group only when the supply of $\mathrm{P}_{4}$ was administered late, from D24 to D29 after the initiation of the FTAI protocol.

Cows supplemented with $\mathrm{P}_{4}$ on days 3 to 6.5 after insemination showed a positive correlation with the embryo survival rate (BELTMAN et al., 2009). Likewise, in a previous study, Mann and Lamming (1999) found that increased conception rates only occurred when $\mathrm{P}_{4}$ was elevated in the first week after insemination, whereas no effect was observed when exogenous $\mathrm{P}_{4}$ was supplemented in the second or third week after insemination. The results obtained by these authors disagree with the findings of the present study, in which improvement of conception rates was observed when $\mathrm{P}_{4}$ was supplemented after the second week following FTAI.

Larson et al. (2007) supplemented dairy cows with $\mathrm{P}_{4}$ on days 3.5 to 10 after $\mathrm{AI}$ and verified an improvement of the conception rate, increasing from $33 \%$ (Control) to $51 \%$ (treated with $\mathrm{P}_{4}$ ). These results differ from those obtained in the present study, in which supplementation with $\mathrm{P}_{4}$ was performed in a time frame similar to that evaluated by Larson et al. (2007), but no improvement of the conception rate was observed in cows supplemented with $\mathrm{P}_{4}$ at an early time point.
Carter et al. (2008) evaluated the effect of a continual increase in $\mathrm{P}_{4}$ from the $3^{\text {rd }}$ day of the oestrous cycle in cows and observed that the use of an intravaginal $\mathrm{P}_{4}$ device inserted on day 3 of the oestrous cycle and left in place until day 5, 7, 13 or 16 , raising the concentration of serum $\mathrm{P}_{4}$, affected embryonic development on days 5 and 7 and increased embryo size on days 13 and 16.

Forde et al. (2011) placed implants in beef heifers on day 3 of the oestrous cycle and observed temporal changes in the endometrium of the cows, which is sensitive to the concentration of circulating $\mathrm{P}_{4}$ in the first days following oestrus, leading to a uterine environment with a reduced ability to induce conceptus elongation under low circulatory $\mathrm{P}_{4}$ conditions.

In several studies in which $\mathrm{P}_{4}$ has been supplemented after FTAI, it has been observed that when $\mathrm{P}_{4}$ is administered earlier, conception rates are increased in cows, contradicting the results of the present study. It is believed that this divergence of results may be due to the mode of action of $\mathrm{MGA}^{\circledR}$ Premix, which may promote an inadequate uterine environment, perhaps by changing the uterine $\mathrm{pH}$, or to anything that could cripple the successful development and growth of the embryo, as early use of this progestin, in the first week following FTAI, reduced conception rates in non-suckling Nelore cows.

\section{Conclusion}

The results of the present study lead to the conclusion that the administration of GnRH in conjunction with FTAI and the oral administration of $\mathrm{MGA}^{\circledR}$ Premix from the $13^{\text {th }}(\mathrm{D} 24)$ to the $18^{\text {th }}$ (D29) day after FTAI increased conception rates in non-suckling Nelore cows. However, when administered on the fifth (D15) and tenth (D20) day after FTAI, the oral provision of $\mathrm{MGA}^{\circledR}$ Premix reduced the conception rate in non-suckling Nelore cows. 


\section{Acknowledgements}

The authors would like to thank the Goiás Research Foundation (Fundação de Amparo à Pesquisa do Estado de Goiás - FAPEG) for financial support of critical importance for the execution of experiments. Thanks also to Reunidas Farm - Agricultural Baumgart and Sara Farm for making available their staff, animals, materials and properties for the development of the experiments.

\section{References}

AHMAD, N.; SCHRICK, F. N.; BUTCHER, R. L.; INSKEEP, E. K. Effect of persistent follicles on early embryonic losses in beef cows. Biology of Reproduction, Champaign, v. 52, n. 5, p. 1129-1135, 1995.

AYAD, A.; SOUSA, N. M.; SULON, J.; HORNICK, J. L.; WATTS, J.; LOPEZ-GATIUS, F.; IGUEROUADA, M.; BECKERS, J. F. Influence of progesterone concentrations on secretory functions of trophoblast and pituitary during the first trimester of pregnancy in dairy cattle. Theriogenology, Stoneham, v. 67, n. 9, p. 15031511, 2007.

BARUSELLI, P. S.; REIS, E. L.; MARQUES, M. O.; NASSER, L. F.; BÓ, G. A. The use of hormonal treatments to improve reproductive performance of anestrous beef cattle in tropical climates. Animal Reproduction Science, Amsterdam, v. 82-83, p. 479-486, 2004.

BAZER, F. W.; SPENCER, T. E.; JOHNSON, G. A.; BURGHARDT, R. C.; WU, G. Comparative aspects of implantation. Reproduction, Cambridge, v. 138, n. 2, p. 195-209, 2009.

BELTMAN, M. E.; LONERGAN, P.; DISKIN, M. G.; ROCHE, J. F.; CROWE, M. A. Effect of progesterone supplementation in the first week post conception on embryo survival in beef heifers. Theriogenology, Stoneham, v. 71, n. 7, p. 1173-1179, 2009.

CALLEJAS, S. S. Fisiología del ciclo estral bovino. In: PALMA, G. A. Biotecnología de la reproducción. Mar del Plata: Reprobiotec, 2001. p. 37-49.

CARTER, F.; FORDE, N.; DUFFY, P.; WADE, M.; FAIR, T.; CROWE, M. A.; EVANS, A. C.; KENNY, D. A.; ROCHE, J. F.; LONERGAN, P. Effect of increasing progesterone concentration from day 3 of pregnancy on subsequent embryo survival and development in beef heifers. Reproduction, Fertility and Development, Melbourne, v. 20, n. 3, p. 368-375, 2008.
CERRI，R. L.; JUCHEM，S. O.; CHEBEL，R. C.; RUTIGLIANO, H. M.; BRUNO, R. G.; GALVÃO, K. N.; THATCHER, W. W.; SANTOS, J. E. Effect of fat source differing in fatty acid profile on metabolic parameters, fertilization, and embryo quality inhigh-producing dairy cows. Journal of Dairy Science, Champaign, v. 92, n. 4, p. 1520-1531, 2009.

COLAZO, M. G.; KASTELIC, J. P.; DAVIS, H.; RUTLEDGE, M. D.; MARTINEZ, M. F.; SMALL, J. A.; MAPLETOFT, R. J. Effects of plasma progesterone concentrations on LH release and ovulation in beef cattle given GnRH. Domestic Animal Endocrinology, Stoneham, v. 34, n. 1, p. 109-117, 2008.

CORRÊA, R. F.; BERGAMASCHI, M. A. C. M.; MACHADO, R. Suporte hormonal com GnRH após a ovulação em vacas de corte. In: JORNADA CIENTÍFICA - EMBRAPA DE SÃO CARLOS, 1., 2009, São Carlos. Anais... São Carlos: [s.n.], 2009. p. 37.

DAHLEN, C. R.; LAMB, G. C.; ZEHNDER, C. M.; MILLER, L. R.; DICOSTANZO, A. Fixed-time insemination in peripueral, lightweight replacement beef heifers after estrus synchronization with PGF2 $\alpha$ and GnRH. Theriogenology, Stoneham, v. 59, n. 8, p. 18271837, 2003.

FERGUSON, J. D.; GALLIGAN, D. T.; THOMSEN, N. Principal descriptors of body condition score in Holstein cows. Journal of Dairy Science, Champaign, v. 77, n. 9, p. 2695-2703, 1994.

FORDE, N.; BELTMAN, M. E.; DUFFY, G. B.; DUFFY, P.; MEHTA, J. P.; O'GAORA, P.; ROCHE, J. F.; LONERGAN, P.; CROWE, M. A. Changes in the endometrial transcriptome during the bovine estrous cycle: effect of low circulating progesterone and consequences for conceptus elongation. Biology of Reproduction, Champaign, v. 84, n. 2, p. 266-278, 2011.

GOTTSCHALL, C. S.; ALMEIDA, M. R.; TOLOTTI, F.; MAGERO, J.; BITTENCOURT, H. R.; MATTOS, R. C.; GREGORY, R. M. Avaliação do desempenho reprodutivo de vacas de corte lactantes submetidas à IATF a partir da aplicação do $\mathrm{GnRH}$, da manifestação estral, da reutilização de dispositivos intravaginais e da condição corporal. Acta Scientiae Veterinariae, Porto Alegre, v. 40, n. 1, p. 1-10, 2012.

GOTTSCHALL, C. S.; MARQUES, P. R.; CANELLAS, L. C. Aspectos relacionados à sincronização do estro e ovulação em bovinos de corte. A Hora Veterinária, Porto Alegre, n. 164, p. 43-48, 2008.

KRUSE, S. G.; ABREU, F.; CRUPPE, L. H.; DAY, M. L.; DIAS, H. P.; BRIDGES, G. A. Effect of progesterone preand post-insemination on pregnancy success on cattle. 
In: CURSO NOVOS ENFOQUES NA PRODUÇÃO E REPRODUÇÃO DE BOVINOS, 17., 2013, Uberlândia. Proccedings... Uberlândia: Conapec Jr, 2013. CD-ROM.

LARSON, S. F.; BUTLER, W. R.; CURRIE, B. W. Pregnancy rates in lactating dairy cattle following supplementation of progesterone after artificial insemination. Animal Reproduction Science, Amsterdam, v. 102, n. 1-2, p. 172-179, 2007.

LOPEZ-GATIUS, F.; SANTOLARIA, P.; MARTINO, A.; DELÉTANG, F.; DE RENSIS, F. The effects of $\mathrm{GnRH}$ treatment at the time of AI and 12 days later on reproductive performance of high producing dairy cows during the warm season in northeastern Spain. Theriogenology, Stoneham, v. 65, n. 4, p. 820-830, 2006.

MANN, G. E.; FRAY, M. D.; LAMMING, G. E. Effects of time of progesterone supplementation on embryo development and interferon- $\tau$ production in the cow. The Veterinary Journal, London, v. 171, n. 3, p. 500-503, 2006.

MANN, G. E.; LAMMING, G. E. The influence of progesterone during early pregnancy in cattle. Reproduction in Domestic Animals, Berlin, v. 34, n. 3-4, p. 269-274, 1999.

MOURA, G. S. Uso de análogos de GnRH após inseminação convencional e com protocolo de IATF em gado mestiço. 2008. Dissertação (Mestrado em Zootecnia) - Universidade Federal de Viçosa, Viçosa, MG.

MURTA, J. E. J.; ANDRADE, V. J.; PEREIRA, J. C. C.; VALE FILHO, V. R. Taxas de prenhez em vacas nelore com a utilização do protocolo CRESTAR para a sincronização do cio. Revista Brasileira de Reprodução Animal, Belo Horizonte, v. 25, n. 1, p. 30-35, 2001.

PERRY, G. A.; PERRY, B. L. GnRH treatment at artificial insemination in beef cattle fails to increase plasma progesterone concentrations or pregnancy rates. Theriogenology, Stoneham, v. 71, n. 5, p. 775-779, 2009.

PFEIFER, L. F. M.; SARTORI, R.; PIVATO, I.; RUMPF, R.; NOGUEIRA, G. P.; XAVIER, E. G.; DIONELLO, N. J. L.; CORREA, M. N. Effect of circulating progesterone on in vitro developmental competence of bovine oocytes. Animal Reproduction, Belo Horizonte, v. 6, n. 3, p. 473478, 2009.
SÁ FILHO, M. F.; SANTOS, J. E.; FERREIRA, R. M.; SALES, J. N.; BARUSELLI, P. S. Importance of estrus on pregnancy per insemination in suckled Bos indicus cows submitted to estradiol/progesterone-based timed insemination protocols. Theriogenology, Stoneham, v. 76, n. 3, p. 455-463, 2011.

SARTORI, R. Fertilização e morte embrionária em bovinos. Acta Scientiae Veterinariae, Porto Alegre, v. 32 p. 35-50, 2004. Suplemento.

SARTORI, R.; FRICKE, P. M.; FERREIRA，J. C.; GINTHER, O. J.; WILTBANK, M. C. Follicular deviation and acquisition of ovulatory capacity in bovine follicles. Biology of Reproduction, Champaign, v. 65, n. 5, p. 1403-1409, 2001.

SATTERFIELD, M. C.; BAZER, F. W.; SPENCER, T. E. Progesterone regulation of preimplantation conceptus growth and galectin 15 (LGALS15) in the ovine uterus. Biology of Reproduction, Champaing, v. 75, n. 2, p. 289296, 2006.

SIQUEIRA, L. C.; OLIVEIRA, J. F. C.; LOGUÉRCIO, R. S. Sistemas de inseminação artificial em dois dias com observação de estro ou em tempo fixo para vacas de corte amamentando. Ciência Rural, Santa Maria, v. 38, n. 2, p. 411-415, 2008

STATISTICAL ANALYSIS SYSTEM - SAS. SAS INSTITUTE. SAS/STAT user's guide. Version 6.03. Cary: SAS Institute INC, 2000. 1028 p.

STRONGE, A. J.; SREENAN, J. M.; DISKIN, M. G.; MEE, J. F.; KENNY, D. A.; MORRIS, D. G. Post-insemination milk progesterone concentration and embryo survival in dairy cows. Theriogenology, Stoneham, v. 64, n. 5, p. 1212-1224, 2005.

WOOD-FOLLIS, S. L.; KOJIMA, F. N.; LUCY, M. C.; SMITH, M. F.; PATTERSON, D. J. Estrus synchronization in beef heifers with progestin-based protocols I. differences in response based on pubertal status at the initiation of treatment. Theriogenology, Stoneham, v. 62, n. 8, p. 1518-1528, 2004. 
